\title{
Embryotoxicity of solanine and aspirin in mice
}

\author{
Deirdre P. Bell, J. G. Gibson, ${ }^{*}$ Anne M. McCarroll and \\ Geraldine A. McClean
}

\author{
Department of Therapeutics and Pharmacology, and Department of Mental Health, \\ The Queen's University of Belfast, Northern Ireland
}

\begin{abstract}
Anencephaly occurs more frequently in Ireland than in most other parts of the world (Coffey \& Jessop, 1957; Elwood \& Warnock, 1969), and the observed seasonal variation in incidence (Edwards, 1958; Leck, 1966; Elwood \& MacKenzie, 1971) suggests that environmental factors may be of some importance. Renwick (1972) proposed that this malformation might be associated with maternal exposure to a potato teratogen of unspecified nature. The teratogen appeared to be more concentrated in certain varieties of potato, particularly in overwintered tubers that are partly blighted or injured. Solanine is an alkaloid found in greater concentration in potatoes which have been exposed to light (Liljemark \& Widoff, 1960), stored for long periods or injured (Gull \& Isenberg, 1960), and there are varietal differences in solanine levels (Liljemark \& Widoff, 1960). Gastrointestinal illness in man has been associated with ingestion of potatoes containing $25 \mathrm{mg}$ solanine $/ \mathrm{kg}$ (Wilson, 1959), and has also been shown to be toxic to mice, rats and rabbits when administered parenterally (Nishie, Gumbmann \& Keyl, 1971). This study was therefore designed to investigate the effects of solanine on pregnancy in mice when given alone, and also in combination with aspirin because aspirin ingestion is one of the commonest forms of self-medication, and may have a potentiating effect.

Adult ASH/CS1 mice weighing 24.05 \pm 6 (S.D.) g were allowed free access to food and water. Females were paired monogamously with males for 4 nights and then randomly allocated to one of 9 groups (Table 1). The first night of pairing was designated as Day 1. All substances were given intraperitoneally; the saline $(0.9 \%)$ in a volume equivalent to that of the treated animals, i.e. about $1 \mathrm{ml} /$ mouse. Commercially extracted solanine (Aldrich Chemical Co., Inc., Milwaukee, U.S.A.) was prepared in a saline solution in a concentration of $0.5 \mathrm{mg} / \mathrm{ml}$. The dosage of soluble aspirin (B.P.; $10 \mathrm{mg} / \mathrm{ml}$ ) was $20 \%$ lower than that for the $\mathrm{LD}_{50}$ given by Barnes \& Eltherington (1964). All the mice were killed on Day 17 and the numbers of live and resorbing fetuses were determined. The results are shown in Table 1.
\end{abstract}

Table 1. The effects of solanine and aspirin on pregnancy in mice

\begin{tabular}{|c|c|c|c|c|c|c|c|}
\hline \multirow[b]{2}{*}{ Groups } & \multirow[b]{2}{*}{ Treatment } & \multirow[b]{2}{*}{$\begin{array}{l}\text { No. of } \\
\text { animals }\end{array}$} & \multirow[b]{2}{*}{$\begin{array}{l}\text { No. not } \\
\text { pregnant }\end{array}$} & \multirow{2}{*}{$\begin{array}{l}\text { No. of } \\
\text { litters } \\
\text { with no } \\
\text { resorp- } \\
\text { tions }\end{array}$} & \multicolumn{2}{|c|}{$\begin{array}{l}\text { No. of mice with } \\
\text { resorptions }\end{array}$} & \multirow{2}{*}{$\begin{array}{c}\text { Total no. } \\
\text { of live } \\
\text { fetuses }\end{array}$} \\
\hline & & & & & $\begin{array}{l}1-25 \% \\
\text { of litter }\end{array}$ & $\begin{array}{c}26-100 \% \\
\text { of litter }\end{array}$ & \\
\hline 1 & Solanine, $20 \mathrm{mg} / \mathrm{kg}$ daily, Days $7-11$ & 20 & 12 & 2 & 1 & 5 & 44 \\
\hline 2 & Solanine, $20 \mathrm{mg} / \mathrm{kg}$, Day 7 & 20 & 0 & 6 & 12 & 2 & 207 \\
\hline 3 & Saline, Days $7-11$ & 10 & 3 & 3 & 4 & 0 & 72 \\
\hline 4 & Saline, Day 7 & 10 & 1 & 4 & 5 & $\mathbf{0}$ & 94 \\
\hline 5 & None & 20 & 3 & 8 & 9 & 0 & 183 \\
\hline 6 & Solanine, $20 \mathrm{mg} / \mathrm{kg}$, Days $7-10$ & 16 & 7 & 3 & 2 & 4 & 67 \\
\hline 7 & Aspirin, $400 \mathrm{mg} / \mathrm{kg}$, Days $7-10$ & 16 & 5 & 4 & 6 & 1 & 118 \\
\hline 8 & $\begin{array}{l}\text { Aspirin, } 400 \mathrm{mg} / \mathrm{kg}+\text { solanine, } \\
20 \mathrm{mg} / \mathrm{kg} \text {, Days } 7-10\end{array}$ & 16 & 14 & 1 & $\mathbf{0}$ & 1 & 9 \\
\hline 9 & Saline, Days 7-10 & 16 & 2 & 8 & 5 & 1 & 155 \\
\hline
\end{tabular}

In the first experiment the greatest toxicity was seen in animals treated with solanine for 5 days. The pregnancy rate of only $40 \%$ in Group 1 mice was significantly reduced $\left(\chi^{2}=6.83 ; P<0.01\right)$

* Deceased. 
compared with $85 \%$ for the controls (Groups 4 and 5 ). There was a corresponding reduction in the total number of live fetuses in Group 1, but there was no significant difference in the number of resorptions. The animals treated with solanine for 1 day only (Group 2) did not differ significantly in either pregnancy rate or resorption rate from controls. A very high toxicity was found for aspirin + solanine for 4 days (Group 8): the pregnancy rate was $12.5 \%$ and was significantly lower than that of $87.5 \%$ for the controls (Group $9: \chi^{2}=15.11 ; P<0.001$ ) and that of $56 \%$ and $69 \%$, respectively, for animals treated with solanine alone (Group 6: $\chi^{2}=4.99 ; P<0.05$ ), or aspirin alone (Group 7: $\chi^{2}=8.29 ; P<0.01$ ). The total number of live fetuses was very small in the Group 8 mice because of the grossly diminished pregnancy rate but there was no significant difference in the number of resorptions in this group compared with those in Groups 6,7 or 9. The animals treated with either aspirin or solanine alone did not differ significantly from controls either in pregnancy rate or number of resorptions. No malformations were observed among the viable fetuses in any of the drug-treated animals.

These results indicate that the alkaloid solanine is embryotoxic when administered parenterally to pregnant mice and that its toxicity is potentiated by aspirin. Since the drugs were administered only after implantation had occurred, the toxic effects were manifested as abortion, indicated by the number of mice that were not pregnant at autopsy, and by resorption of some or all of the embryos in the litters that did survive.

The effects were not as great in animals treated with solanine alone for less than 5 days, and suggests two possible mechanisms of action, (1) that the toxic effect may be cumulative and depend on a critical drug level being reached in the animal, and/or (2) that the fetus is vulnerable at a particular stage of gestation. With regard to (1), Nishie et al. (1971) found that in rats given $25 \mathrm{mg}$ solanine/ $\mathrm{kg}$ excretion of the substance via faeces and urine suddenly diminished and was followed by a rapid accumulation of solanine in many tissues of the body. An investigation of a wide range of toxic dose levels might reveal a specific dose at which abortion and fetal death would be replaced by fetal malformation. For (2), it has been shown that the veratrum alkaloid, 11-deoxojervine, causes a cyclopian deformity in all lambs only when given to the ewe on the 14th day of gestation (Binns, James \& Shupe, 1965). No malformations were observed in the small number of live fetuses of our mice treated with solanine or solanine + aspirin for 5 days.

Poswillo et al. (1973) found no teratogenic activity in extracts of imperfect potatoes given to marmosets, and Clark, McKendrick \& Sheppard (1973) found no significant difference in the consumption of potatoes by 83 mothers of spina bifida children and matched controls. The effect of solanine may be species specific. Somers (1962) noted that thalidomide appeared to cause only resorptions in rats but was associated with fetal malformations in rabbits. It cannot be extrapolated from our experiments in mice that potatoes in the human diet contribute in any way to the incidence of anencephaly, but the possibility that commonly used drugs like aspirin may potentiate the embryotoxic effects of other dietary factors warrants further investigation.

Financial support for this work was given by the Northern Ireland Hospitals Authority, the Medical Research Council and the Wellcome Foundation. Thanks are due to Professor O. L. Wade, Professor P. C. Elmes, Dr C. H. Williams, Dr J. H. Elwood and Dr N. C. Nevin for their interest in this work, to Dr K. MacRae for statistical advice, and to Miss B. Bassett for her clerical assistance.

\section{References}

BARnes, C.D. \& Eltherington, L.G. (1964) A Handbook of Drug Dosage in Laboratory Animals, p. 24. University of California Press, Berkeley and Los Angeles.

Binns, W., James, L.F. \& Shupe, J.L. (1965) Embryopathic activity of a poisonous range plant, Veratrum californicum. In The Embryopathic Activity of Drugs, pp. 105-109. Eds. J. M. Robson, F. M. Sullivan \& R. L. Smith. Churchill, London.
Clark, C.A., McKendrick, O.M. \& Sheppard, P.M. (1973) Spina bifida and potatoes. Br. med. J. 3, 251-254.

COFFEY, V. \& Jessop, W.J.E. (1957) A study of 137 cases of anencephaly. Br.J. prev. soc. Med. 11, $175-180$

EDWARDS, J.H. (1958) Congenital malformations of the central nervous system in Scotland. Br.J. prev. soc. Med. 12, 115-130. 
Elwood, J.H. \& MacKenzIE, G. (1971) Comparisons of secular and seasonal variations in the incidence of anencephalus in Belfast and four Scottish cities, 1956-66. Br.J. prev. soc. Med. 25, 17-25.

Elwood, J.H. \& WARNOck, H.A. (1969) Anencephalus in Belfast and Dublin. Ir.J. med. Sci. 2, 17-25.

GulL, D.D. \& IsenBERG, F.M. (1960) Chlorophyll and solanine content and distribution in four varieties of potato tubers. Proc. Am. Soc. hort. Sci. 75, 545-556.

LECK, I. (1966) Changes in the incidence of neural tube defects. Lancet 2, 791-793.

LiLJemark, A. \& WidOFF, E. (1960) Greening and solanine development of white potato in fluorescent light. Am. Potato J. 37, 379-389.
Nishie, K., GumbmanN, M.R. \& KeyL, A.C. (1971) Pharmacology of solanine. Toxic. appl. Pharmac. 19, 81-92.

Poswillo, D.E., Sopher, D., Mitchell, S.J., Coxon, D.T., Curtis, R.F. \& Price, K.R. (1973) Further investigations into the teratogenic potential of imperfect potatoes. Nature, Lond. 244, 367-368.

RENwICK, J.H. (1972) Hypothesis. Anencephaly and spina bifida are usually preventable by avoidance of a specific but unidentified substance present in potato tubers. Br.J. prev. soc. Med. 26, 67-88.

SOMERS, G.F. (1962) Thalidomide and congenital abnormalities. Lancet 1, 912-913.

WiLson, J.S. (1959) A small outbreak of solanine poisoning. Mon. Bull. Minist. Hlth 18, 207-210.

Received 26 June 1975 